\title{
Synthesis, Spectral and Antibacterial Studies of Metal Complexes Derived from 2-[1-(2-Aminobenzylimino)- ethyl]phenol
}

\author{
R.U. SHILPA ${ }^{1,2}$, P. RANJITH REDDY ${ }^{1}$ and PALLAPOTHULA VENKATESHWA RAO ${ }^{* 1}$ \\ ${ }^{1}$ Department of Chemistry, University College of Science, \\ Osmania University, Hyderabad-500 007, India \\ ${ }^{2}$ Department of Chemistry, P.G.College of Science, Saifabad, \\ Osmania University, Hyderabad-500 004, India \\ pallapothulav@gmail.com
}

Received 23 May 2016 / Accepted 4 June 2016

\begin{abstract}
A novel Schiff base ligand is derived from ortho-hydroxy acetophenone and 2substituted amine and its transition metal complexes with $\mathrm{Cu}(\mathrm{II}), \mathrm{Ni}(\mathrm{II}), \mathrm{VO}(\mathrm{IV}), \mathrm{Cd}(\mathrm{II})$ have been synthesized and characterized by analytical data, conductance and magnetic susceptibility measurements, UV Visible near IR, Mass, IR spectra and ${ }^{1} \mathrm{H}$ NMR spectral data. The results are indicating that the ligand coordinates through azomethine nitrogen, amine nitrogen and phenolic oxygen to the metal ions. The spectral data indicate that the ligand is behaving as a monobasic terdentate ligand. The mass spectral data and ${ }^{1} \mathrm{H}$ NMR spectral data confirmed the proposed structure of the ligand.
\end{abstract}

Keywords: 2-Aminobenzylimine, Antibacterial activity, Complexes

\section{Introduction}

Schiff bases and their metal complexes have been found to possess important biological and catalytic activities $^{1,2}$. Due to their great flexibility and diverse structural aspects, a wide range of Schiff bases have been synthesized and their complexation behaviour was studied ${ }^{3}$. Schiff bases are typical in connection with a diverse range of applications such as in organic synthesis $^{4-7}$, as liquid crystals ${ }^{8}$ and as heterogeneous catalysts ${ }^{9}$. We report here the synthesis of Schiff base ligands (HL) and its $\mathrm{Cu}(\mathrm{II}), \mathrm{Ni}(\mathrm{II}), \mathrm{Cd}(\mathrm{II})$ and $\mathrm{VO}(\mathrm{IV})$ complexes.

\section{Experimental}

All the chemicals used were of AR grade. All the solvents were purified by reported methods before use ${ }^{10}$. Double distilled water has been used where ever necessary. Copper(II) and Vanadium(II) as sulphates, Cadmium(II) and Nickel(II) as chloride salts were purchased from Merck. 
Melting Points were determined with Bock Monoscope Wreck NR instrument. Electrical conductivity of the metal complexes was studied at room temperature with freshly prepared $1 \times 10^{-3} \mathrm{M}$ solutions in DMSO using Digisun Conductometer Model DI 909. UV Visible spectra were recorded on a UV Visible near IR Varian Cary 5E instrument. IR spectra (KBr discs) were recorded on a Bruker IFS-66V FT IR spectrophotometer. ${ }^{1} \mathrm{H}$ NMR spectra were recorded on Bruker Avance $300 \mathrm{MHz}$ spectrometer using TMS as standard. ESI mass spectrum was recorded on LC MSD Trap SL mass spectrometer. The elemental analyses (C, H and $\mathrm{N}$ ) of the complexes were carried out on Perkin-Elmer $240 \mathrm{C}$ (USA) elemental analyzer. Metal estimations were carried out using a Varian Spectra AA 20 atomic absorption spectrometer. The magnetic susceptibility measurements were carried out on a Faraday Balance at room temperature using $\mathrm{Hg}\left[\mathrm{Co}(\mathrm{SCN})_{4}\right]$ as calibrant.

\section{Preparation of the ligand}

The ligand was prepared by taking ortho-hydroxy acetophenone and 2-amino benzyl amine in methanol in 1:1 molar ratio and refluxing for 3- 6 hours. Then 1-2 drops of sulphuric acid was added. Upon cooling, a yellow coloured solid separates out was filtered and dried (Scheme 1).<smiles>CC(=O)c1ccccc1O</smiles><smiles>NCc1ccccc1N</smiles>

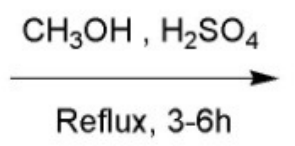<smiles>C/C(=N\Cc1ccccc1N)c1ccccc1O</smiles>

Scheme 1. Preparation of 2-[1-(2-aminobenzylimino)ethyl]phenol ligand

\section{Synthesis of metal complexes}

Metal(II) chloride / sulphate hexahydrate $(1 \mathrm{mmol})$ in $\mathrm{MeOH}$ was added gradually and with constant stirring to a solution of ligand, the stoichiometry of the metal ion to ligand was 1:1. The solution was heated for some time. The $\mathrm{pH}$ of the reaction mixture was adjusted to 7-8 using ammonia solution. Upon cooling overnight the metal chelates were separates out. These were filtered by suction, washed with methanol followed by petroleum ether and dried in vacuum at $60-80{ }^{\circ} \mathrm{C}$ (Scheme 2-5).<smiles>C/C(=N/Cc1ccccc1N)c1ccccc1O</smiles>

Scheme 2. Preparation of Ni complex<smiles>CC(=NCc1cc[cH+]ccc1N)c1ccccc1O</smiles>

Scheme 3. Preparation of VO complex 


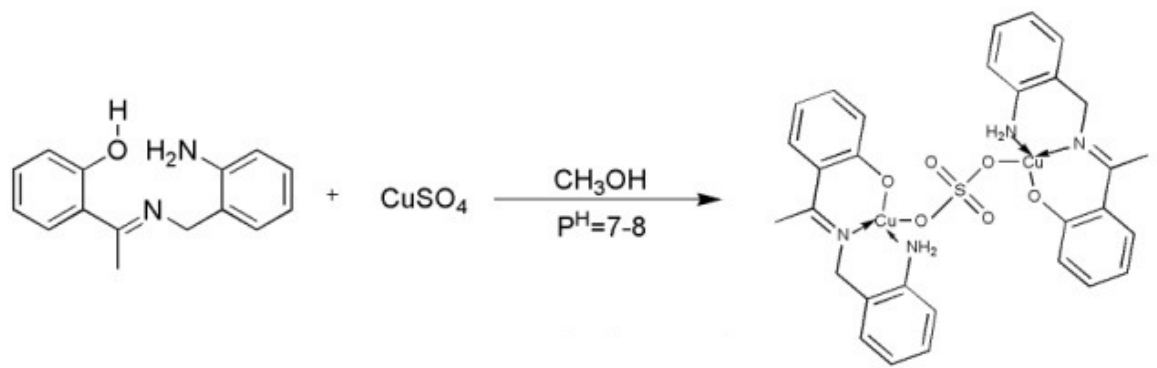

Scheme 4. Preparation of $\mathrm{Cu}$ complex<smiles>C/C(=N/Cc1ccccc1N)c1ccccc1O</smiles><smiles>[B]C([B])([GeH2])CO</smiles>

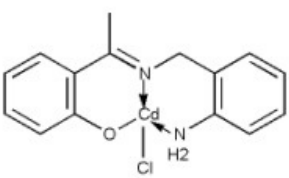

\section{Biological activity}

Scheme 5. Preparation of Cd complex

\section{Media and culture conditions}

2.4\% MH media (Muller Hinton media) was used for culturing the microorganisms. The prepared plates with microorganisms were incubated at $37^{\circ} \mathrm{C}$ for overnight.

\section{Preparation of agar plates}

$2.4 \mathrm{~g}$ of $\mathrm{M} \mathrm{H}$ media was weighed and dissolved in $100 \mathrm{~mL}$ of distilled $\mathrm{H}_{2} \mathrm{O}$, then autoclaved. The media was cooled to $45^{\circ} \mathrm{C}$ then it was poured into five sterile boiling test tubes $20 \mathrm{~mL}$ each. For each tube different cultures were used $(20 \mu \mathrm{L})$, then these cultures were poured in to sterile Petri plates and they were allowed to solidify. Standardization of antibiotic property of the samples was to different concentrations $(100-250 \mu \mathrm{g})$.

\section{Testing of samples}

The solidified MH agar plates were taken and made grooves with borer. Then samples of transition metal complexes with $\mathrm{Cu}(\mathrm{II}), \mathrm{Ni}(\mathrm{II}), \mathrm{VO}(\mathrm{IV})$ and $\mathrm{Cd}(\mathrm{II})$ were added in sterile conditions to the grooves and the plates were cooled to room temperature then kept in incubator at $37^{\circ} \mathrm{C}$ for overnight. Then the activity of samples was measured in diameter of zone of inhibition.

\section{Results and Discussion}

The analytical data of the ligand and their metal complexes are given in the Table 1. This is in agreement with the proposed structures of the ligand and its complexes. All the metal chelates are coloured. They are stable to air and moisture. The complexes decompose around 250-300 ${ }^{\circ} \mathrm{C}$. They are insoluble in water. But they are soluble in organic solvents like ethanol, DMF, DMSO and dioxane. Molar conductance measurements in DMSO solution indicate that they are non electrolytic in nature ${ }^{11}$.

\section{Characterization of ligand and metal complexes}

\section{IR spectral data}

The reaction of Schiff base, HL with $\mathrm{VO}(\mathrm{IV}), \mathrm{Ni}(\mathrm{II}), \mathrm{Cu}(\mathrm{II})$ and $\mathrm{Cd}(\mathrm{II})$ metal ions produce a new series of binuclear and mononuclear metal complexes. The analytical and physical data of the ligand and metal complexes are listed in Table 1. 
Table 1. Analytical data and physical properties of the ligand and complexes

\begin{tabular}{|c|c|c|c|c|c|c|}
\hline \multirow{2}{*}{$\begin{array}{l}\text { Composition of } \\
\text { Ligand/Complex }\end{array}$} & \multirow{2}{*}{ Colour } & \multirow{2}{*}{$\begin{array}{l}\text { Melting } \\
\text { point }\end{array}$} & \multicolumn{4}{|c|}{$\%$ Found (Calcd.) } \\
\hline & & & Carbon & Hydrogen & Nitrogen & Metal \\
\hline $\mathrm{C}_{15} \mathrm{H}_{16} \mathrm{ON}_{2}$ & Yellow & $115^{\circ} \mathrm{C}$ & $\begin{array}{c}75.10 \\
(75.00)\end{array}$ & $\begin{array}{c}6.52 \\
(6.67)\end{array}$ & $\begin{array}{c}11.01 \\
(11.66)\end{array}$ & $\begin{array}{l}- \\
-\end{array}$ \\
\hline$\left[\mathrm{VO}\left(\mathrm{C}_{15} \mathrm{H}_{15} \mathrm{ON}_{2}\right)\right]_{2} \mathrm{SO}_{4}$ & $\begin{array}{l}\text { Greenish } \\
\text { blue }\end{array}$ & $>300{ }^{\circ} \mathrm{C}$ & $\begin{array}{r}69 . \\
69 .\end{array}$ & $\begin{array}{c}5.20 \\
(5.18)\end{array}$ & $\begin{array}{r}10 \\
(10\end{array}$ & \\
\hline$\left[\mathrm{Ni}\left(\mathrm{C}_{15} \mathrm{H}_{15} \mathrm{ON}_{2}\right) \mathrm{Cl}\right]$ & & $>300{ }^{\circ} \mathrm{C}$ & $\begin{array}{c}66.50 \\
(66.46)\end{array}$ & $\begin{array}{c}5.63 \\
(5.70)\end{array}$ & $\begin{array}{l}10.10 \\
(10.07)\end{array}$ & $\begin{array}{l}19.52 \\
(19.60)\end{array}$ \\
\hline$\left[\mathrm{Cu}\left(\mathrm{C}_{15} \mathrm{H}_{15} \mathrm{ON}_{2}\right)\right]_{2} \mathrm{SO}_{4}$ & $\begin{array}{l}\text { Dark } \\
\text { green }\end{array}$ & $>300{ }^{\circ} \mathrm{C}$ & $\begin{array}{c}69.00 \\
(69.30)\end{array}$ & $\begin{array}{c}5.16 \\
(5.18)\end{array}$ & $\begin{array}{c}10.31 \\
(10.33)\end{array}$ & $\begin{array}{l}21.00 \\
(21.13)\end{array}$ \\
\hline$\left[\mathrm{Cd}\left(\mathrm{C}_{15} \mathrm{H}_{15} \mathrm{ON}_{2}\right) \mathrm{Cl}\right]$ & White & $>300{ }^{\circ} \mathrm{C}$ & $\begin{array}{c}64.61 \\
(64.69)\end{array}$ & $\begin{array}{c}5.79 \\
(5.85)\end{array}$ & $\begin{array}{c}9.90 \\
(9.91)\end{array}$ & $\begin{array}{c}32.08 \\
(32.28)\end{array}$ \\
\hline
\end{tabular}

Solubility: Ligand in Methanol and complexes in DMSO

The characteristic IR bands of the ligand and its complexes listed in Table 2. In the IR spectrum of the ligand (HL), $v(\mathrm{~N}-\mathrm{H}), v(\mathrm{O}-\mathrm{H})$ (phenolic), $v(\mathrm{C}=\mathrm{N})$ and $v(\mathrm{C}=\mathrm{O}$ ) stretching vibrations were observed at 3600,3362, 1608 and $1304 \mathrm{~cm}^{-1}$ respectively. Figure 1 shows the azomethine vibration of the ligand at $1608 \mathrm{~cm}^{-1}$ was shifted to lower frequencies after complexation, appearing at 1603,1601, 1598 and $1571 \mathrm{~cm}^{-1}$ for Copper(II), Nickel(II), Vanadium(IV) and Cadmium(II) complexes respectively, indicating the participation of azomethine nitrogen of $v(\mathrm{C}=\mathrm{N})$ in complexation ${ }^{12}$. The $v(\mathrm{~N}-\mathrm{H})$ vibration of the ligand at $3610 \mathrm{~cm}^{-1}$ was shifted to lower frequencies after complexation, appearing at 3410,3580 , 3450 and $3505, \mathrm{~cm}^{-1}$ for Copper(II), Nickel(II), Vanadium(IV) and Cadmium(II), complexes respectively, indicating the participation of amine nitrogen of $v(\mathrm{~N}-\mathrm{H})$ in complexation ${ }^{12}$. On the other hand, the $v(\mathrm{C}-\mathrm{O})$ (phenolic) band at $1304 \mathrm{~cm}^{-1}$ in the free ligand was moved to a higher frequency by $20-50 \mathrm{~cm}^{-1}$ after complexation indicates the participation of phenolic oxygen of $\mathrm{C}-\mathrm{O}$ in complex formation ${ }^{13,14}$. The IR frequencies observed for metal complexes in the region of 515-755 and 410-578 $\mathrm{cm}^{-1}$ are attributed to $v(\mathrm{M}-\mathrm{N})$ and $v(\mathrm{M}-\mathrm{O})$ IR stretching frequencies. On the basis of IR spectral data it is inferred that the ligand is behaving as a monobasic terdentate ligand with $\mathrm{O}: \mathrm{N}: \mathrm{N}$ donor sequence.

\section{${ }^{1} H$ NMR spectral data}

The ${ }^{1} \mathrm{H}$ NMR spectrum of the ligand 2-[1-(2-Aminobenzylimino)ethyl]phenol was recorded in DMSO- $\mathrm{d}_{6}$. The spectrum shows characteristic signals of the ligand in $\delta(\mathrm{ppm})$. Signals are observed at $\delta 12.0\left(\mathrm{~s}, \mathrm{H}_{7},-\mathrm{OH}\right), \delta 4.6\left(\mathrm{~s}, 2-\mathrm{H}_{10}, \mathrm{CH}_{2}\right.$ of benzyl), $\delta$ 7.8-6.64 (arom-H) and $\delta 3.4\left(\mathrm{~s}, 3 \mathrm{H}_{17}\right)$ respectively and the $\mathrm{NH}$ hydrogen appears as broad singlet at $\delta 11.07$. All the signals correlate very well with the proposed structure of the ligand ${ }^{15}$.

Table 2. FT- IR spectral data Schiff Base and its various metal complexes

\begin{tabular}{|c|c|c|c|c|c|c|c|c|c|}
\hline Ligand/Complex & 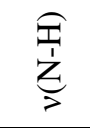 & $\underbrace{\stackrel{9}{1}}_{>}$ & 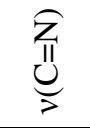 & 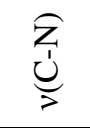 & $\begin{array}{c}v(\mathrm{C}-\mathrm{O}) \\
\text { Phenolic }\end{array}$ & 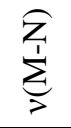 & 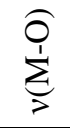 & 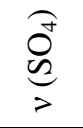 & $\begin{array}{l}\text { UV-Vis } \\
\mathrm{nm}\end{array}$ \\
\hline $\mathrm{C}_{15} \mathrm{H}_{16} \mathrm{ON}_{2}$ & 3610 & 3362 & 1608 & 1216 & 1304 & - & - & - & 258 \\
\hline$\left[\mathrm{VO}\left(\mathrm{C}_{15} \mathrm{H}_{15} \mathrm{ON}_{2}\right)\right]_{2} \mathrm{SO}_{4}$ & 3450 & 3350 & 1598 & 1183 & 1333 & 519 & 442 & 1133 & $630-800$ \\
\hline$\left[\mathrm{Ni}\left(\mathrm{C}_{15} \mathrm{H}_{15} \mathrm{ON}_{2}\right) \mathrm{Cl}\right]$ & 3580 & 3318 & 1601 & 1190 & 1329 & 536 & 480 & - & $450-630$ \\
\hline$\left[\mathrm{Cu}\left(\mathrm{C}_{15} \mathrm{H}_{15} \mathrm{ON}_{2}\right)\right]_{2} \mathrm{SO}_{4}$ & 3410 & 3290 & 1603 & 1201 & 1338 & 618 & 441 & 1116 & $450-850$ \\
\hline$\left[\mathrm{Cd}\left(\mathrm{C}_{15} \mathrm{H}_{15} \mathrm{ON}_{2}\right) \mathrm{Cl}\right]$ & 4305 & 3339 & 1571 & 1205 & 1383 & 555 & 412 & - & $450-630$ \\
\hline
\end{tabular}




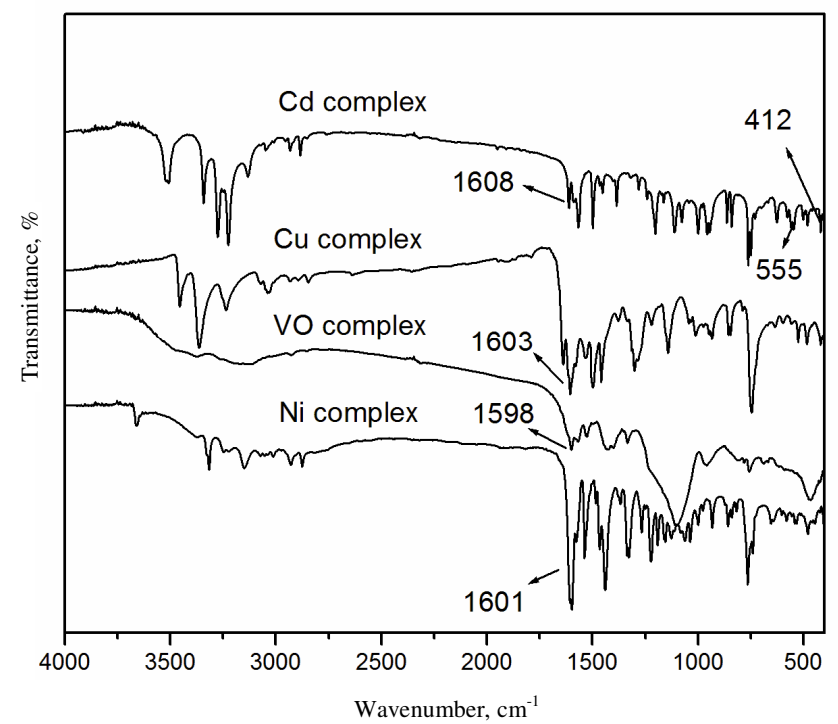

Figure 1. FT-IR Spectra of metal complexes

\section{Mass spectral Data}

ESI mass spectrum of the ligand shows a base peak at $\mathrm{m} / \mathrm{z} 240,241\left(\mathrm{M}^{+}+1\right)$. It shows various fragments at $\mathrm{m} / \mathrm{z} 224$ and $\mathrm{m} / \mathrm{z} 200$, confirming the same molecular weight, which is same as the calculated $\mathrm{M}^{+}$values.

\section{Electronic spectra of metal complexes}

The electronic spectrum of the ligands and all the complexes were recorded in DMSO at room temperature, the electronic spectrum of the $\mathrm{VO}(\mathrm{IV})$ complex shows three absorption bands at 11363, 15265 and $22222 \mathrm{~cm}^{-1}$. These are assigned to ${ }^{2} \mathrm{~B}_{2} \leftarrow{ }^{2} \mathrm{E} ;{ }^{2} \mathrm{~A}_{1} \leftarrow{ }^{2} \mathrm{E}$ and ${ }^{2} \mathrm{~B}_{2} \leftarrow{ }^{2} \mathrm{E}$ transitions. Square pyramidal geometry can be assigned to the complex.

The electronic spectrum of the Ni(II) complex shows absorption bands at 15873 and $20000 \mathrm{~cm}^{-1}$. These are interpreted to ${ }^{1} \mathrm{~A}_{1 \mathrm{~g}} \leftarrow{ }^{1} \mathrm{E}_{\mathrm{g}}$ and ${ }^{1} \mathrm{~B}_{1 \mathrm{~g}} \leftarrow{ }^{1} \mathrm{E}_{\mathrm{g}}$. Based on these assignments a square planar geometry has been proposed to the complex. The UV Visible spectrum of the $\mathrm{Cu}$ (II) complex shows broad absorption bands in the region $12500 \mathrm{~cm}^{-1}$ and $15873 \mathrm{~cm}^{-1}$, based on this it has been assigned to ${ }^{2} \mathrm{~B}_{2} \leftarrow{ }^{2} \mathrm{E} ;{ }^{2} \mathrm{~A}_{1} \leftarrow{ }^{2} \mathrm{E}$ and ${ }^{2} \mathrm{~B}_{1} \leftarrow{ }^{2} \mathrm{E}$ transitions. The electronic absorption spectrum suggests a square pyramidal geometry with a metal- metal bonding in the solid state ${ }^{16}$.

\section{Magnetic spectral data}

The magnetic susceptibility measurements of the complexes have been carried out at room temperature. The VO (IV) complex exhibits a magnetic moment of $1.90 \mathrm{~B}$. M. This value is in correlation with the single unpaired electron in the complex with square pyramidal disposition.

The Ni(II) complex is diamagnetic and red in colour. So a square planar disposition has been assigned to the complex. The $\mathrm{Cu}$ (II) complex exhibits a magnetic moment of 1.04 B.M. The value is according to the single unpaired electron present in the complex. But the lower magnetic moment is due to the antiferromagnetic interaction between the two $\mathrm{Cu}(\mathrm{II})$ metal centres. The $\mathrm{Cu}(\mathrm{II})$ complex may be assigned a dimeric square planar structure. 
The ligand and its various complexes formed from $\mathrm{VO}(\mathrm{IV}), \mathrm{Ni}(\mathrm{II}), \mathrm{Cd}(\mathrm{II})$ and $\mathrm{Cu}(\mathrm{II})$ have been tested. Clear inhibition was noticed with the ligand and complexes. It was noticed that the vanadium complex has shown the highest inhibition followed by other complexes and the ligand shown in the Table 3. The biological evaluations of the simple ligand in comparison to their metal complexes have been determined against bacterial strain ${ }^{17}$. Generally, it is suggested that the chelated complexes deactivate various cellular enzymes, which play a vital role in various metabolic pathways of these micro organisms ${ }^{18-22}$.

Table 3. Biological activity of the ligand and metal complexes

\begin{tabular}{|c|c|c|c|c|}
\hline Microbial species & Ligand & NiL & $\mathrm{CuL}$ & VL \\
\hline Salmonella typhimurium & +++ & - & ++ & +++ \\
\hline Staphylococcus aureus & ++ & - & ++ & +++ \\
\hline Staphylococcus epidermidis & ++ & - & ++ & +++ \\
\hline Klebsiella рпиетопiae & ++ & - & ++ & +++ \\
\hline Eschirichia coli & ++ & - & ++ & +++ \\
\hline Bacillus subtilis & +++ & - & ++ & ++ \\
\hline Listeria monocytogenes & +++ & - & +++ & ++ \\
\hline MRSA-I $^{c}$ & +++ & - & ++ & +++ \\
\hline MRSA-II & +++ & - & ++ & +++ \\
\hline MRSA-IIII & ++ & - & ++ & ++ \\
\hline
\end{tabular}

*Inhibition zone diameter $(\mathrm{mm})=+\sim=6-10,++\sim=10-13,+++\sim=14-16 ;-=$ No zone of inhibition, Concentration of all compounds $=100-250 \mu \mathrm{g}$

\section{Conclusion}

The synthesis of novel ligand from ortho-hydroxy acetophenone and 2-substituted amine and its metal complexes with $\mathrm{Cu}(\mathrm{II}), \mathrm{Ni}(\mathrm{II}), \mathrm{VO}(\mathrm{IV}), \mathrm{Cd}(\mathrm{II})$ and their biological activity have been demonstrated. Their structures were characterized by analytical data, conductance and magnetic susceptibility measurements and UV Visible, FT-IR, Mass and ${ }^{1} \mathrm{H}$ NMR spectral data. The results indicate that the ligands coordinate through azomethine nitrogen, amine nitrogen and phenolic oxygen to the metal ions.

\section{Acknowledgement}

One of the authors Ms. Shilpa is thankful to the Principal, P.G.College of Science, Saifabad for providing research laboratory. We are also thankful to Md. Sathar, V. Shekar IICT for IR, NMR and Mass spectral analysis. We show our gratitude to Head, department of chemistry, Osmania University for providing facility to carry out magnetic susceptibility measurements.

\section{References}

1 Wah Henri L K, Tagenine J and Minu B, Indian J Chem., 2001, 40, 999-1003.

2 Soliman A A \& Mohaamed G G, Thermochim Act, 2004, 421, 151.

3 Vaghasiya Y K, Nair R, Soni M, Chanda S and Serb J, Chem Soc., 2004, 69(12), 991-998.

$4 \quad$ Katsuki T, Coord Rev., 1995, 140, 189-214; DOI:10.1016/0010-8545(94)01124-T

$5 \quad$ Ito Y N and Katsuki T, Bull Chem Soc Jpn., 1998, 72(4), 603-619.

6 Pospisil P J, Carsten D H and Jacobsen E N, Chem A Eur J., 1996, 2(8), 974-980; DOI:10.1002/chem.19960020812

7 Katsuki T, J Mol Catal A: Chem., 1996, 113(1-2), 87-107; DOI:10.1016/S13811169(96)00106-9

8 Hoshino N, Coord Chem Rev., 1998, 174(1), 77-108; DOI:10.1016/S00108545(98)00129-5 
9 Canali L and Sherrington D C, Chem Soc Rev., 1999, 28, 85-93; DOI:10.1039/A806483K

10 Vogel's text book of Practical Organic Chemistry, $5^{\text {th }}$ Ed., (Longmans, London) 1989.

11 Ravinder V, Int J Chem Sci., 2007, 5(2), 489-495.

12 Soliman A A and Linert W, Thermochemical Acta, 1999, 333(1), 67-71; DOI:10.1016/S0040-6031(99)00105-7

13 Birader N S and Kulkarni V H P, J Inorg Nucl Chem., 1971, 33(11), 3781-3786.

14 Ruddick J N R and Sams J R, Organnomet Chem., 1973, 60(2), 233-246; DOI:10.1016/S0022-328X(00)80645-2

15 Kemp W, Organic spectroscopy, (ELBS, Hampshire) 1987, 105.

16 Kivelson D and Neiman R, J Phy Chem., 1961, 35, 149-155.

17 Chohan Z H and Mushtaq S, Pakistan J Pharm Sci., 2000, 13(1), 21-27.

18 Franklin T J and Snow G A, Biochem Antimicrobial Action, $2^{\text {nd }}$ Ed., (Chapman \& Hall, London) 1971.

19 Mehmet S, Metin C and Ismet B, Eur J Med Chem., 2010, 45(5), 1935-1940; DOI:10.1016/j.ejmech.2010.01.035

20 Prasad S, Jayaseelam P and Rajavel R, Inter J Pharm Tech., 2010, 2, 694.

21 Sellappan R, Prasad S, Jayaseelam P and Rajavel R, Rasayan J Chem., 2010, 3, 556.

22 Vedanayaki S, Jayaseelan P, Sandanamalar D and Rajavel R, Asian J Chem., 2011, 23, 407. 